\title{
Strategi Pemasaran Produk Asuransi Syariah Di PT. Prudential Life Assurance Cabang Kota Medan
}

\author{
Febby Ayu Syahputri Gurning ${ }^{1}$, Nuri Aslami ${ }^{2}$ \\ Asuransi Syariah, Fakultas Ekonomi dan Bisnis Islam, Universitas Islam Negeri \\ Sumatera Utara, Medan Indonesia \\ Email : ${ }^{1}$ febbyayugurning@gmail.com, ${ }^{2}$ Nuriaslami@uinsu.ac.id
}

\begin{abstract}
Human life in modern times has various kinds of risks and dangers. Man himself does not know what will happen tomorrow and where he will die world. Insurance is a financial tool for managing home life, both in terms of facing an underlying risk, such as the chance of mortality, and in terms of protecting one's personal belongings. In the marketing process, a strategy is needed essential, the company's main target in a broad market reach. So that a strategy is required before entering the market, all of the plans have been consolidated, comprehensive, And included to make sure that the company's last purpose may be found out via the implementation of the suitable strategy. Study The reason for this observation is to choose and evaluate (segmentation, targeting, and positioning) at PT. Prudential Life Assurance Medan City Branch, in addition to to decide whether or not the advertising plan is carried out according with sharia advertising characteristics. This study employs a qualitative technique while doing descriptive research. The findings revealed that the market segmentation (segmenting) conducted by PT. Prudential Life Assurance Medan City Branch based on per market grouping region. To make it easier for Prudential to meet and greet its customers return. Targeting, in determining the target market covered by PT. Prudential Life Assurance Medan City Branch there is no certain limit, the company serves all market segment.
\end{abstract}

Keywords : Strategy, Marketing, Sharia Insurance, PT. Prudential Life Assurance Branch Medan City.

\begin{abstract}
Di dunia sekarang ini, ada berbagai resiko dan bahaya. Seseorang tidak mengerti apa yang terjadi besok atau di mana dia akan mati. Asuransi adalah alat keuangan untuk mengelola kehidupan keluarga, baik dalam hal mengatasi risiko dasar seperti kematian dan bahaya terhadap harta benda seseorang. Sangat penting untuk menerapkan strategi penting dalam proses pemasaran, dengan tujuan utama perusahaan adalah jangkauan pasar yang luas. Jadi, sebelum memasuki pasar, diperlukan strategi yang merinci semua rencana yang telah disusun, lengkap dan terintegrasi, serta memastikan mencapai tujuan utama perusahaan melalui penerapan pendekatan yang benar. Tujuan studi ini adalah memeriksa dan mengkaji strategi (segmentasi, targeting, dan positioning) menilai apakah rencana pemasaran yang digunakan oleh PT Prudential Life Assurance Cabang
\end{abstract}


Kota Medan memenuhi standar pemasaran syariah. Penelitian ini menggunakan teknik kualitatif dengan melakukan penelitian deskriptif. Temuan mengungkapkan bahwa perusahaan tersebut melakukan segmentasi pasar (Segmenting) berdasarkan penggolongan pasar berdasarkan wilayah. Prudential akan lebih mudah bertemu dan menyapa konsumennya. Penargetan tidak memiliki batasan dalam menentukan target pasar yang akan dicakup oleh PT. Prudential Life Assurance Cabang Kota Medan; perusahaan melayani semua segmen pasar.

Kata kunci : PT. Prudential Life Assurancee Cabang Kota Medan, Strategi, Pemasaran, Asuransi Syariah.

\section{PENDAHULUAN}

Di dunia sekarang ini, ada berbagai macaam risiko. Manusia berisiko dari berbagai bahaya, termasuk insiden di transportasi udara, laut, dan darat. Kecelakaan kerja, kebakaran, perampokan, pencurian, sakit, bahkan kematian adalah semua risiko yang dihadapi manusia. Masa depan adalah ketidakpastian yang tidak dapat diprediksi. Risiko biasanya dibarengi dengan ketidakpastian. Siapa yang mau mengambil kesempatan untuk masa depan kita? Dengan menyisihkan sebagian dari kekayaan kita untuk memenuhi tuntutan masa depan yang tidak pasti, kita adalah pembawanya. Berinvestasi, menabung, atau membayar premi asuransi semuanya dapat digunakan untuk menyediakan aset untuk masa depan. Seseorang mungkin dipersiapkan secara finansial untuk masa depan dengan membeli asuransi (Muhammad, 2018).

Dalam bukunya, Philip Kotler (1992) mengatakan bahwa strategi pemasaran yang solid dibangun di atas tiga (3) pilar fundamental: segmentasi, targeeting, dan posiitioning. Dimana pemisahan ini memudahkan pedagang untuk memenuhi kebutuhan pelanggan dengan mengkategorikannya ke dalam kelompok yang berbeda berdasarkan bagaimana mereka bereaksi terhadap item tertentu. Karena mereka sudah tahu siapa dan bagaimana melayani mereka, organisasi lebih fokus melayani pelanggan pada saat ini. Dalam rangkaian penargetan pasar sasaran, mengidentifikasi pasar merupakan tahap evaluasi segmen. Penargetan pasar adalah alat yang ampuh untuk mengidentifikasi kemungkinan segmen pasar yang kemudian dapat digunakan sebagai target. Prospek pasar potensial tidak diragukan lagi dapat ditentukan untuk memaksimalkan pendapatan.

Gedung Selecta 2nd floor, JL. Listrik, No. 2, Petisah Tengah, Medan Petisah, Kota Medan, Sumatera Utara 20212, Indonesia adalah rumah bagi Prudential Life Assurance Cabang Medan Kota. Objek dengan latar belakang dipilih untuk berbagai tujuan. Untuk memulai, perusahaan ini berbeda dengan perusahaan prudential lainnya karena hanya menerima nasabah asuransi syariah. Kedua, setiap bulan dalam 6 bulan terakhir, jumlah konsumen diperusahaan asuransi ini mengalami peningkatan. Selanjutnya, pendekatan pemassaran yang digunakan oleh PT Prudential Life Assurance Cabang Kota Medan didasarkan pada prinsip-prinsip pemasaran syariah. Peneliti tertarik untuk melakukan penelitian tentang "Strategi Pemasaran STP (Segmenting, Targeting, and Positioning) Produk Asuransi Syariah Pada PT. Prudential Life Assurance Cabang Kota Medan" berdasarkan latar belakang di atas. 


\section{KAJIAN TEORI \\ a. Strateegi Pemasaran}

Strateegi pemasaran yaitu penalaran peemasaran yang digunakan perusahaan untuk mencapai tujuan pemasaran unit bisnisnya. Strategi khusus, positioning, bauran pemasaran, dan jumlah kompetisi pemasaran untuk pasar sasaran adalah bagian dari strategi pemasaran (Kotler \& Armstrong, 2001). Pemasaran sendiri ialah hasil dari usaha karyawan dalam kegiatan komersial termasuk transfer barang serta jasa dari penjual ke pelanggan. Teori pemasaran adalah filosofi manajemen pemasaran berfokus pada kebutuhan serta keinginan pelanggan, lewat upaya pemasaran terpadu untuk memberi kepuasan pelanggan seumpama kunci keberhasilan perusahaan dalam mencapai tujuannya. Pengertian pemasaran adalah pola pikir perusahaan, yang menegaskan bahwa tujuan utama perusahaan adalah untuk mendeteksi kebutuhan serta keinginan pasar, berikutnya memeenuhi kebutuhan dan keinginan tersebut untuk mencapai tingkat kepuasan berlangganan yang lebih tinggi dari pesaing (Assauri, 2019). Pemasaran Islami wajib memiliki persepsi nilai yang tinggi dan merek yang baik karena bisnis Islam didasarkan pada kepercayaan, keadilan, dan tidak adanya penipuan. Pemasar syariah, selain mematuhi aturan syariah, juga menikmati semua larangan-Nya secara sukarela, patuh, dan nyaman, berkat dorongan internal dan kekuatan eksternal (H.F., Aravik \& Aravik, 2020).

\section{b. Segmentasi Pasar (Segmenting)}

Segmentasi adalah proses di mana pasar membagi pelanggannya ke dalam kelompok berdasarkan persyaratan dan karakteristik mereka, dan kemudian mengarahkan mereka untuk menanggapi tawaran produk. Pasar terdiri dari kelompok pembeli yang beragam, yang masing-masing berbeda dalam satu atau lebih aspek. Seseorang dapat berbeda dalam hal kebutuhan, keuangan, sumberdaya, sifat pembelian, dan pola pembelian. Perusahaan membagi pasar yang luas dan bervariasi menjadi pasar yang lebih kecil yang dapat ditembus secara efisien dengan produk dan layanan yang memenuhi permintaan khusus konsumen melalui segmentasi pasar (Kotler \& Armstrong, 2001).

Pembagian pasar adalah strategi pemasaran ini didasarkan pada ide manajemen pemasaran yang berpusat pada konsumen. Upaya pemasaran memungkinkan Anda untuk menargetkan upaya pemasaran Anda dengan lebih baik dan menggunakan sumber daya pemasaran perusahaan Anda secara lebih efisien dan efektif. Segmentasi ini membagi pasar yang bervariasi jadi kelompok produsen atau konsumen yang memiliki kualitas yang sama dan dapat menguntungkan perusahaan. Melalui upaya pemasaran perusahaan, kategorikategori ini akan dievaluasi dan dipertimbangkan untuk dipilih sebagai target pasar. Perusahaan dapat menggunakan segmentasi pasar untuk mengidentifikasi dan menganalisis prospek pasar yang ada, melakukan perbaikan produk atau program bisnis pemasaran, dan memperkirakan pengeluaran bisnis pemasaran berdasarkan karakteristik segmen (Assauri, 2019).

\section{c. Penargetan Pasar( Targeting)}

Setelah melakukan segmentasi pasar menjadi beberapa segmen, pasar yang akan dibidik dipilih. Karena sumber daya perusahaan terbatas, penargetan merupakan pendekatan yang efektif untuk mendistribusikannya. Operasi 
pemasaran ditargetkan pada target pasar tertentu untuk mendapatkan hasil yang diinginkan. Pasar sasaran adalah sekumpulan konsumen yang relatif homogen dimana perusahaan ingin mengembangkan strategi untuk menarik serta membeli produk yang diinginkan.

\section{d. Penempatan Posisi (Positioning)}

Pada intinya, penempatan atau positioning mengacu pada proses menciptakan kesan tertentu di benak pelanggan sehingga mereka dapat mendalami serta menghargai apa yang dicapai perusahaan dibandingkan dengan pesaingnya. Perusahaan kemungkinan besar bakal ditempatkan di sub-segmen sektor pasar yang telah dipilihnya. Akibatnya, perusahaan yang berjuang untuk "posisi berkualitas tinggi" di pasar akan menarik "segmen konsumen berkualitas tinggi". Namun, kita dapat memilah antara segmen dan segmen dengan celah (niche). Sebagai contoh, jika salah satu segmen yang dilayani adalah kontraktor listrik yang mencari pasangan bata beton, organisasi kami dapat memilih celah (atau memposisikan dirinya) untuk menawarkan konsumen berkualitas tinggi di pasar ini (Kotler, 1992).

\section{e. Asuransi Syariah}

Menuruti Fatwa DSN No. 21/DSN-MUI/X/2001 tentang Pedoman Umum Asuransi Syariah menyebutkan bahwa asuransi syariah adalah upaya saling melindungi dan tolong menolong antara banyak orang atau pihak melalui penanaman harta dan atau tabarru', yang memberikan pola untuk menangani risiko tertentu melalui atau keterlibatan (Nopriansyah, 2018).

Tujuan asuransi ada tiga bagian diantaranya , tujuan tertanggung, dan tujuan penanggung adalah ketiga tujuan asuransi syariah. Jika tertanggung menderita kerugian, ganti rugi penanggung berusaha untuk membawa tertanggung keluar dari pailit sehingga ia dapat mempertahankan posisi seperti sebelum kerugian Asuransi tidak dapat memberikan manfaat kepada tertanggung, sehingga lebih menguntungkan. Demikian pula, penanggung tidak dapat mengambil untung dari risiko yang ditanggungnya kecuali jika ia menerima imbalan atau premi.

\section{f. Karakteristik Syariah Marketing}

Fitur empatik teisstis (rabbaniyyah), etis (akhlaqiyyah), realistis (alwaqi'iyyah), dan humanistis (rabbaniyyah) dari pemasaran islami dapat menjadi panutan bagi pemasar (insaniyyah). Teistis (rabbaniyyah) adalah fitur pemasaran syariah yang tidak hanya dimiliki oleh pemasaran tradisional, yang selalu dikaitkan dengan agama. Atribut kedua adalah etiks (akhlaqiyah), yang merupakan hasil dari sifat teistik (rabbaniyah). Pemasaran syariah, apapun agamanya, merupakan ide pemasaran yang merepresentasikan nilai-nilai Akhlak dan Etika. Ketiga, merupakan gagasan yang realisstis (al-waqi'iyyah) daripada gagasan eksklusif, obsesif, anti-modern, dan dogmatis. Pemasaran syariah adalah gagasan yang dapat digunakan dalam berbagai cara. Keempat, adalah humanistik universal (al-insyaniyyah).(Zamzam, H. F., \& Aravik, 2020).

\section{METODE PENELITIAN}

Penelitian ini menggunakan penelitian kualitatif. Penelitian ini dilakukan oleh PT PrudeEntial Life Assurance Cabang Medan Kota di Gedung Selecta Lantai 2, Jl 
Electric, No. 2, Petisah Tengah, Medan Petisah, Kota Medan, Sumatera Utara. Wawancara, observasi, dan dokumentasi adalah semua pendekatan untuk mengumpulkan data. Dalam penelitian ini, reduksi data digunakan sebagai teknik analisis data. Karena begitu banyak data yang diperoleh di lapangan, maka harus dicatat dengan cermat.

\section{HASIL PENELITIAN DAN PEMBAHASAN a. Strateegi Segmenting}

Segmentasi pasar klien berdasarkan tuntutan dan sifat serupa yang mendorong mereka untuk menanggapi penawaran produk melalui segmentasi strategis. PT Prudential Life Assurance Cabang Kota Medan menggunakan segmentasi untuk memudahkan pelaku usaha dalam memasarkan produk dan jasanya. Nasabah dibagi menjadi beberapa kelompok berdasarkan pekerjaan mereka, seperti karyawan swasta, mahasiswa, aktor, pegawai negeri, Muslim, dan non-Muslim, oleh Asuransi Prudential.

Pada perusahaan ini,klien dikategorikan berdasarkan kesamaan latar belakang dengan produk yang diberikan kepada calon pelanggan. Perusahaan ini melakukan segmentasi pasar berdasarkan pengelompokan pasar berdasarkan wilayah. Prudential akan lebih mudah bertemu dan menyapa konsumennya.

Perusahaan ini melakukan proses pengelompokan segmen pasar. Pengelompokan ini ditentukan untuk mencerminkan perkembangan pasar yang akan dibidik ke depan. Penetapan segmen merupakan contoh satu faktor yang nantinya akan menjadi pertimbangan dalam menentukan program-program yang ditawarkan oleh perusahaan ini. Cabang Kota Medan dari perusahaan ini melayani masyarakat umum untuk setiap kelompok atau konsumen yang ingin mendapatkan asuransi dan berinvestasi tanpa harus memulai bisnis.

\section{b. Strategi Targeting}

Penempatan target pasar (targeting) adalah proses perusahaan yang berfokus pada pasar tertentu. Target pasar perusahaan disesuaikan dengan kebutuhan segmen pasar, daya beli, dan kemampuan yang terbatas. PT. Prudential Life Assurance Cabang Kota Medan tidak memiliki kendala dalam memilih target pasar yang dilayaninya, perusahaan melayani semua tanpa berfokus pada elemen tertentu. PT. Prudential Life Assurance Cabang Kota Medan menghadirkan berbagai program dan produk. Tujuannya adalah untuk menjangkau semua orang. Solusi yang ada dirancang untuk memungkinkan konsumen dari semua latar belakang dan kapasitas untuk terlibat dalam asuransi berdasarkan anggaran dan kemampuan mereka..

\section{c. Strategi Positioning}

Positioning ialah suatu usaha yang dilakukan oleh perusahaan. Upaya perusahaan dalam mendesain produk untuk menimbulkan kesan dan citra positif di benak konsumen, sebagaimana dimaksud, sehingga tidak ada keraguan lagi. Banyak orang yang tidak memiliki polis dan banyak orang yang membeli asuransi setelah didekati oleh agen perusahaan asuransi dapat menyaksikan bahwa barang asuransi belum menjadi kebutuhan banyak konsumen. Hal ini juga berlaku untuk PT asuransi Prudential Life Assurance Cabang Kota Medan. 
Penyediaan layanan prima, produk berkualitas, Organisasi ini memiliki visi untuk jadi peritel jasa keuangan terbesar di Indonesia, menjangkau pelanggan, pemasar, staf, dan pemegang saham melalui pemasar terampil dan sangat berdedikasi, dan menghasilkan keuntungan. Perusahaan juga melakukan jenis positioning lainnya, seperti kejujuran dan akurasi. Tuduhan tersebut adalah di mana konsumen mengeluh tentang kurangnya kejujuran dan ketepatan waktu. Orang yang ragu untuk membeli asuransi karena klaim asuransi syariah bisa jadi sulit untuk diajukan. Anda tidak akan kecewa dengan filosofi kejujuran dan pelayanan yang cepat dari asuransi syariah. Konsumen tidak akan kecewa jika manajemennya jujur dan pelayanannya cepat. Konsumen akan memiliki tempat khusus di hati mereka untuk kejujuran dalam manajemen dan layanan yang luar biasa.

Wujud positioning yang dilakukan PT. Prudential Life Assurance Cabang Kota Medan yaitu dengan slogannya yaitu "Always Listening, Always Understanding". Prudential memahami bahwa ia hanya dapat memahami apa yang dibutuhkan kliennya untuk kenyamanan dan keamanan hidup dan keluarga mereka dengan mendengarkan dengan seksama. Prudential akan siap mendengarkan apa yang dibutuhkan konsumen dan membuat perencanaan terbaik berdasarkan kebutuhan tersebut, sebagaimana tertuang dalam motto prudential.

\section{d. Strategi Pemasaran Produk Asuransi Syariah pada PT. Prudential Life Assurance Cabang Kota Medan dalam Karakteristik Syariah Marketing}

Ada empat aspek pemasaran syariah yang dapat dijadikan pedoman bagi pemasar: teistik (rabbaniyah), etis (akhlaqiyyah), realistis (al-waqi'iyyah), dan humanistik (rabbaniyah) (insaniyah). Komponen Islami dari pemasaran syariah (rabbaniyyah) adalah salah satu fitur yang tidak diklaim oleh pemasaran tradisional (diniyyah). Jiwa marketer syariah meyakini bahwa aturan syariah teoritis atau ilahiah saat ini ialah hukum yang paling adil, sempurna, dan sempurna dalam semua manifestasinya, mampu mencapai kebenaran, menghilangkan ketidakadilan, dan menyebarkan keuntungan. Dalam semua aspek aktivitasnya, etika (akhlaqiyyah) juga cukup bermoral.

Syariah marketing ialah ide pemasaran yang mengutamakan kualitas moral dan etika, apapun agamanya. Semua agama mengajarkan konsep moral dan etika. Realis (al-waqi'iyyah) digambarkan dengan istilah-istilah seperti pemasaran syariah, ide-ide khas, kemelekatan, anti-modernitas, dan kekakuan. Pemasaran Islami adalah strategi pemasaran multifaset. Pemasar syariah, apapun gaya berpakaiannya, adalah pemasar yang berpakaian rapi dan sederhana. Dalam semua upaya pemasaran mereka, mereka bekerja secara profesional dan mengutamakan keyakinan agama, kesalehan, kualitas moral, dan kejujuran. Sikap kemanusiaan (al-insaniyyah) Syariah dibentuk untuk manusia dalam rangka menaikkan derajatnya dan memelihara karakter kemanusiaannya. Karena nilai-nilai kemanusiaannya, ia menjadi manusia yang tertib dan seimbang, bukan manusia egois yang menghalalkan segala cara untuk menambah rejeki.

Menurut penelitian, pendekatan pemasaran perusahaan ini termasuk pemasaran syariah, yang menyoroti empat komponen pemasaran syariah yaitu dramatis, etis, realistis, dan humanistik. 
5. PENUTUP

\section{a. Kesimpulan}

Sebagaimana dikemukakan di atas, PT. Prudential Life Assurance Cabang Kota Medan melakukan segmentasi pasar (Segmentation) berdasarkan pengelompokan pasar berdasarkan wilayah. Prudential akan lebih mudah bertemu dan menyapa konsumennya. Tidak ada kendala dalam memilih target pasar (targeting) yang dicakup oleh PT. Prudential Life Assurance Cabang Kota Medan; organisasi melayani semua tanpa berfokus pada elemen tertentu. Cabang Kota Medan dari PT. Prudential Life Assurance menghadirkan berbagai program dan produk. PT. Strategi positioning Prudential Life Assurance yang didasarkan pada tagline "Always Listening, Always Understanding". Prudential ini mengakui bahwa hanya dengan mendengarkan secara seksama dan hati-hati, ia dapat memahami apa yang dituntut konsumennya untuk kenyamanan dan keamanan mereka sendiri, serta keluarga mereka.

Menurut penelitian, Prudential Life Assurance Cabang Kota Medan telah menggunakan pemasaran syariah, yang berfokus pada empat pilar pemasaran syariah: dramatis, etis, realistis, dan humanistik.

\section{b. Saran}

Dengan bermitra dengan berbagai instansi di Medan, PT. Prudential Life Assurance Cabang Kota Medan memperluas segmentasi pasar untuk produk individu dan memperluas jangkauan konsumen. PT. Prudential Life Assurance Cabang Kota Medan terus berbenah dalam mengenali peluang atau peluang dengan tujuan meminimalkan kerentanan dan persaingan di masa depan.

\section{DAFTAR RUJUKAN}

Assauri, Sofjan., 2019, Manajemen Pemasaran, Jakarta:PT Raja Grafindo Persada.

Kasali, R. 2005. Membidik Pasar Indonesia: Segmentasi, Targeting, dan Positioning. Cetakan Ketujuh. Jakarta: PT Gramedia Pustaka Utama.

Kotler, Philip., 1992, Management, Sixt Edition, alih bahasa Jaka Wasana, Manajemen Pemasaran Jilid 1 Ed.6, Jakarta: Erlangga.

Kotler, Philip., Amstrong, Gary., 2001, Principles of Marketing 8 edition, alih bahasa Damos Sihombing, Prinsip-Prinsip Pemasan Jilid I Ed.,8, Jakarta: Erlangga.

Muhammad., 2017, Lembaga Perrkonomian Islam, Medan: UPPSTIM YKPN.,

Nopriansyah, Waldi., 2018, Asuransi Syariah Berkah Terakhir yang Tak Terduga, Medan: ANDI

Suhendi, Hendi., Yusuf, Deni K., 2005, Asuransi Takaful dari Teoritis Ke Praktik, Bandung: Mimbar Pustaka

Zamzam, H. F., \& Aravik, H. 2020. Etika Bisnis Islam Seni Berbisnis Keberkahan. Deepublish. 